\title{
Variation in Chemical Constituents of Siyez Wheat (Triticum monococcum L.) in Response to Some Abiotic Stress Factors
}

\author{
Nezahat Turfan ${ }^{1, a, *}$, Temel Sarıyıldız ${ }^{2, b}$, Ekrem Mutlu $^{3, c}$ \\ ${ }^{I}$ Department of Biology, Faculty of Arts and Sciences, Kastamonu University, 37200 Kastamonu, Turkey \\ ${ }^{2}$ Department of Forest Engineering, Faculty of Forestry, Bursa Technical University, 16310 Bursa, Turkey \\ ${ }^{3}$ Aquaculture Department, Faculty of Fisheries, Kastamonu University, 37200 Kastamonu, Turkey \\ *Corresponding author
}

A R T I C L E I N F O
Research Article

A B S T R A C T

Main aim of this study was to determine the effects of different salt contents $(75 \mathrm{mM}, 150 \mathrm{mM}$ and $225 \mathrm{mM} \mathrm{NaCl})$, heavy metal $\left(0.2 \mathrm{mg} / \mathrm{L} \mathrm{FeCl}_{3}, \mathrm{NiCl}_{2}, \mathrm{ZnCl}_{2}\right)$, lime $(2 \mathrm{mg} / \mathrm{L} \mathrm{CaCO} 3)$, drought $(50 \%)$ and pollution $(0.2 \mathrm{mg} / \mathrm{L}$ dust of factories) on photosynthetic pigments, malondialdehyde (MDA), hydrogen peroxide $\left(\mathrm{H}_{2} \mathrm{O}_{2}\right)$ levels, the ascorbate peroxidase (APX), catalase (CAT),

Received : 15/10/2018

Accepted : 21/12/2018 guaiacol peroxidase (GPOX) and superoxide dismutase (SOD) in Siyez wheat (Triticum monococcum L.). All experiments were carried out under laboratory conditions with 16 hour-day and 8 hour-night photoperiod in an incubator at $23 \pm 1{ }^{\circ} \mathrm{C}$. Results showed that mean chlorophylla concentration was highest in the siyez seedlings treated with the pollution, while both mean chlorophyll-b and total chlorophyll concentrations were highest with $75 \mathrm{mM}$ salt application. Mean total carotenoid was, however, highest with the drought treatment and mean relative water

\section{Keywords:}

Abiotic stresses

Siyez content was highest with $\mathrm{NiCl}_{2}$ application. Mean MDA and $\mathrm{H}_{2} \mathrm{O}_{2}$ contents were found to be highest in the siyez seedlings treated with $225 \mathrm{mM}$ salt, whereas they were lowest with $\mathrm{NiCl}_{2}$ treatment. Mean proline content was highest with the $\mathrm{NiCl}_{2}$ treatment compared to the lowest concentration in the control siyez seedlings $(82 \mu \mathrm{mol} / \mathrm{g})$. Mean APX, CAT and GPOX activities

Tolerance

Wheat were noted to be highest in the siyez seedlings treated with $\mathrm{NiCl}_{2}$. In general, the siyez seedlings showed high tolerance to the pollution, $\mathrm{NiCl}_{2}$ and drought with having highest photosynthetic pigments, proline, protein content and enzymes activities. Among all treatments, $225 \mathrm{mM} \mathrm{NaCl}$ and $\mathrm{CaCO}_{3}$ negatively influenced chemical compounds of the siyez seedling. When all data are taken into consideration, it can be said that higher photosynthetic pigments, proline contents, antioxidant enzymes activities and lower MDA and $\mathrm{H}_{2} \mathrm{O}_{2}$ levels play an important role in the resistance of siyez seedlings against abiotic stress conditions.

Türk Tarım - Gıda Bilim ve Teknoloji Dergisi 7(4): 598-605, 2019

\section{Siyez Buğday Çeşidinin Kimyasal Bileşenlerinin Bazı Abiyotik Stres Koşullarına Karşı Değişimi}

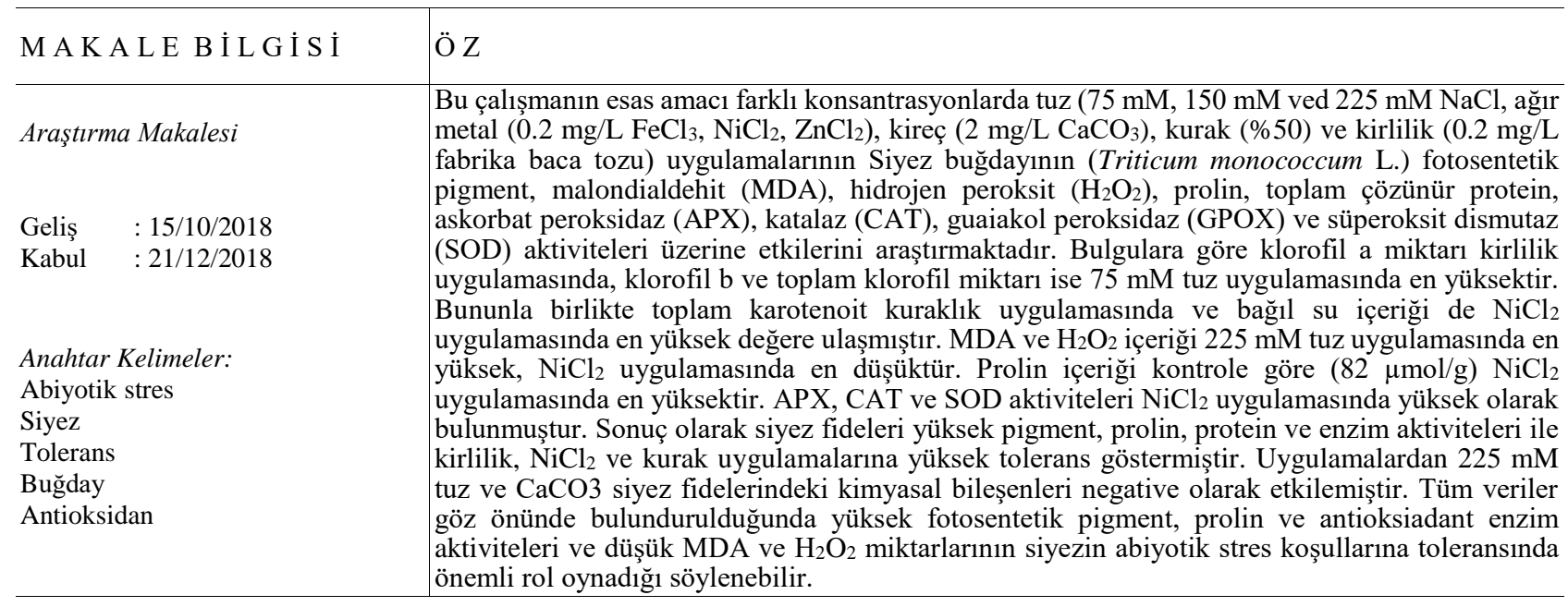




\section{Introduction}

Wheat (Triticum L. spp.) is one of the most important cereal crops around the world, which can be cultivated in a wide variety such as temperate, high-rainy areas and warm, dry and cold environment. It has over 713 million tons in 2013 as annual production (Faostat, 2014). However, generally warm and drought climatic conditions create the ideal environment for salinity and barrenness formation in any region where the wheat grows (Başer et al., 2005). On the other hand, the accumulation of zinc, iron, lead, cadmium, nickel and other heavy metals in dense industrial zones which are close to cultivation lands affect wheat crop production by leading to heavy metal toxicity ( Mutlu et.al., 2013; Mutlu et.al., 2014; Mutlu et.al., 2016; Mutlu and Kurnaz, 2017; Barut et al., 2017; Kurnaz and Turfan, 2017; Sarıyıldız et al., 2017; Mutlu and Kurnaz, 2018). Many authors stated that salinity, heavy metals and element toxicity, excessive calcerous soil and also drought especially before grain filling may reduce leaf and stem properties such as leaf area, length of leaf, length and strength of internode (Ostrowska et al., 2014; Turky1lmaz et al., 2018). It has been reported that deviations from optimal growth and development of crops repress photosynthetic activity which is main factor on grain quality and yield (Saeidi and Abdoli, 2016; Konuşkan et al., 2017). On the other side, those conditions can stimulate oxidative stress that leads to disruption of chloroplast structure, destruction of photosynthetic pigments, degradation protein and amino acid, inhibition of enzymes, increasing free radicals and malondildeyde (Neto et all., 2006; Turkyilmaz et., 2014). Due to the increased nutrient requirements and the limited availability of agricultural lands, in parallel with population increase, selecting wild and improved genotypes with high tolerance to stress factors in regions where salinity, lime/drought and heavy metal toxicity are dominant will contribute to more efficient utilization of existent land resources. In this context, Siyez (einkorn) grown well around Kastamonu region is an important ancestral gene source. It has been reported that einkorn is an ancient wheat which originates in the mountainous areas of Turkey and its wild progenitor (T. baeoticum Boiss.) (Lùje et al., 2003). In addition, compared to common wheat, einkorn is generally more resistant to diseases and has the ability to withstand drought, but the yields of einkorn are less compared to the common wheat variety (Shewry and Hey, 2015; Nakov et

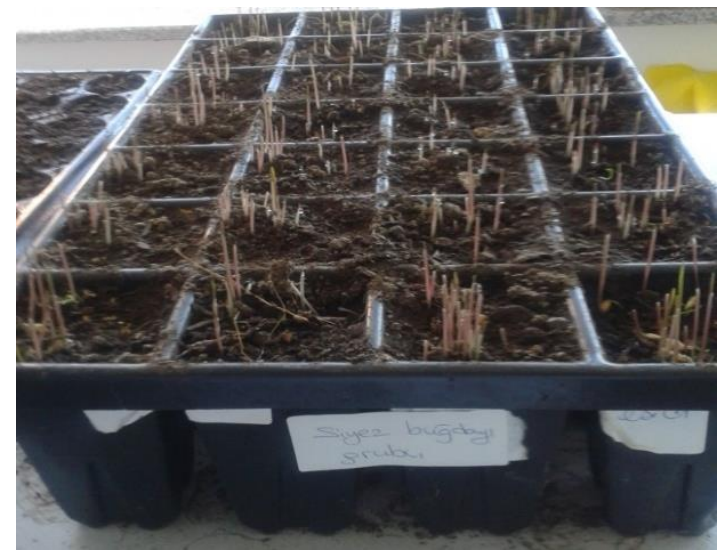

al., 2016). San et al., (2015) analysed the polymorphism in seed endosperm proteins for Turkish cultivated einkorn wheat (Triticum monococcum ssp. monococcum). They showed that it had the the high number of proteins and genetic variation, and increased interest in organic products. In order to better understand the mechanism of resistance to stress factors, the determination of morphological parameters as well as physiological measurements in different wheat varieties can provide us more accurate steps to select the appropriate species and varieties. We, therefore set up a study to investigate the effects of salt, heavy metals, drought and lime treatments on the green parts photosynthetic pigments, proline, total soluble protein, MDA, $\mathrm{H}_{2} \mathrm{O}_{2}$ amount and APX, CAT, GPOX and SOD activities were siyez wheat (Triticum monococcum $\mathrm{L}$.). We used $\mathrm{FeCl}_{3}, \mathrm{NiCl}_{2}$ and $\mathrm{ZnCl}_{2}$ in this present study in order to understand the effects of the heavy metal on siyez wheat since those three heavy metals are known to reduce plant growth and also they are the elements in the components of photosynthesis, carbohydrate and respiratory reactions.

\section{Materials and Methods}

\section{Laboratory Incubations}

All experiments were carried out under laboratory conditions with 16 hour-day and 8 hour-night photoperiod in an incubator at $23 \pm 1^{\circ} \mathrm{C}$. The seeds were planted in the plastic seeding pots (Figure 1) containing 1:1:1 garden soil, peat and sand (tree replicate each) and placed in the incubators until analyses (Figure 2). In order to apply salt, heavy metal, $\mathrm{CaCO}_{3}$ and pollution to the seedlings, each treatment group was dissolved in ArnonHoagland (Hoagland and Arnon, 1950) nutrient solution. The nutrient solution consisted of $2.5 \mathrm{mM} \mathrm{NO}_{3}{ }^{-}, 0.5 \mathrm{mM} \mathrm{NH}_{4}{ }^{+}, 2 \mathrm{mM}$ $\mathrm{K}^{+}, 1 \mathrm{mM} \mathrm{Ca}{ }^{2+}, 0.5 \mathrm{mM} \mathrm{Mg}{ }^{2+}, 0.05 \mathrm{mM}$ Fe-EDTA, $5 \&$ $\mathrm{mu} ; \mathrm{M} \mathrm{Mn}^{2+}, 0.5 \& \mathrm{mu} ; \mathrm{M} \mathrm{Zn}^{2+}, 0.5 \& \mathrm{mu} ; \mathrm{M} \mathrm{Cu}^{2+}, 1 \mathrm{mM}$ $\mathrm{Cl}, 0.55 \mathrm{mM} \mathrm{SO}_{4}^{-2}, 0.5 \mathrm{mM} \mathrm{PO}_{4}^{-3}, 1.5 \& \mathrm{mu} ; \mathrm{M} \mathrm{BO}_{3}, 0.1$ $\& \mathrm{mu} ; \mathrm{M} \mathrm{MoO}_{4}$. The applications were made twice a week as stress application and only once a week as nutrient solution. In each case $25 \mathrm{ml}$ was added. The drought application was carried out using $12.5 \mathrm{ml}$ according to the soil susceptibility, while the nutrient solution and $25 \mathrm{ml}$ were applied on the control group. All applications were carried out for 5 weeks.

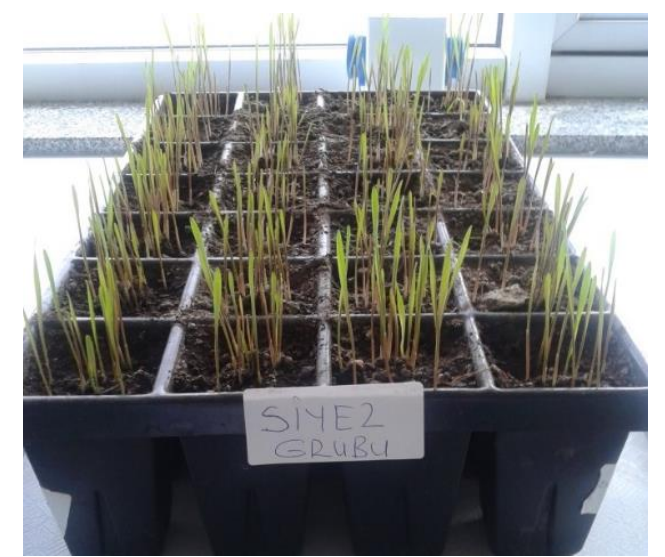

Figure 1 The siyez seeds were planted in the plastic pots (left). The development of the siyez seedlings under laboratory conditions (right) 

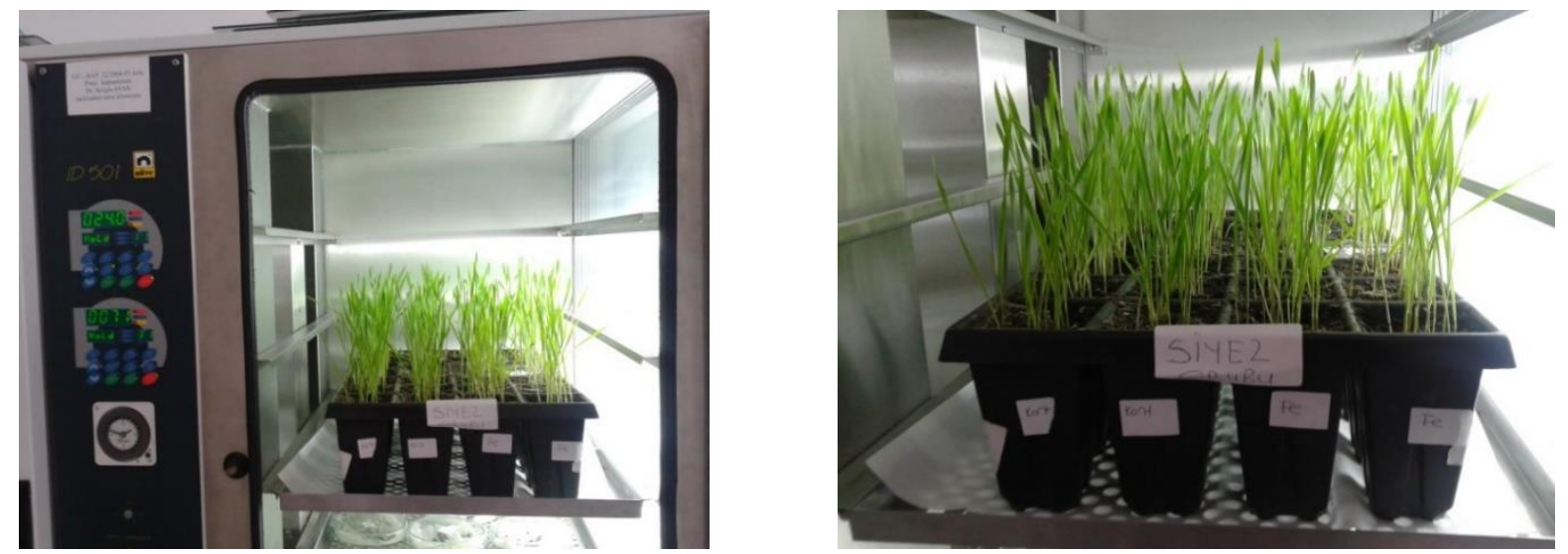

Figure 2 The growing siyez seeding treated with different amount salt, heavy metals, drought, $\mathrm{CaCO}_{3}$ and pollutant were kept in the incubators for 5 weeks

\section{Chemical Analyses}

The leaf samples were collected at the end of the fifth week and analysed for photosynthetic pigments (chlorophyll- a, chlorophyll-b and carotenoids), proline, total soluble protein, glucose, sucrose, total soluble sugar, peroxidation level (MDA-malondialdehyde), hydrogen peroxide $\left(\mathrm{H}_{2} \mathrm{O}_{2}\right)$ and antioxidants such as ascorbate peroxidase (APX), catalase (CAT) and superoxide dismutase (SOD) activities. Analyses were carried out in triplicate. Chlorophyll content of the leaf sample was measured by the method of Arnon (1949). For this, $500 \mathrm{mg}$ of leaf samples were extracted with $80 \%$ acetone and centrifuged at $3000 \mathrm{rpm}$ for 15 minutes. The extract was utilized for chlorophyll estimation. Carotenoid amount was estimated by Jaspars Formula according to the method by Witham et al. (1971). Proline content of leaf tissues was estimated spectrophotometrically following the ninhydrin method described by Bates et al. (1973). $500 \mathrm{mg}$ of leaf sample were homogenized in $3 \%$ of sulphosalicylic acid. Samples were mixed, centrifuged at $10.000 \times \mathrm{g}$ for $15 \mathrm{~min}$, and added on the supernatants $2 \mathrm{~mm}$ glacial acetic acid and ninhydrin reagent $83 \%(\mathrm{w} / \mathrm{v})$ ninhydrin in $60 \%(\mathrm{v} / \mathrm{v}) 6 \mathrm{M}$ phosphoric acid) in order. All samples were kept at at $90^{\circ} \mathrm{C}$ for $1 \mathrm{~h}$. After icecooling, $4 \mathrm{ml}$ cooling toluene poured on the samples, and then the absorbance of the upper (toluene) phase was determined at $520 \mathrm{~nm}$ against a zerotime blank. Proline concentrations were calculated using proline standards (0-100 $\left.\mathrm{g} \mathrm{mL}^{-1}\right)$ in identical manner. The level of lipid peroxidation products was determined using the thiobarbioturic (TBA) method which decompose and product of peroxidized polyunsaturated fatty acid component of membrane lipids.500 mg sample were homogenized in $5 \mathrm{ml} 0.1 \%(\mathrm{w} / \mathrm{v})$ trichloroacetic acid (TCA) using a chilled mortar and pestle. The homogenate was centrifuged at $15,000 \mathrm{~g}$ for $15 \mathrm{~min}$. To $1 \mathrm{ml}$ aliquot of supernatant, $4 \mathrm{ml} 0.5 \%(\mathrm{w} / \mathrm{v})$ thiobarbituric acid (TBA) in $20 \%(\mathrm{w} / \mathrm{v})$ TCA was added. The mixture was heated at $95^{\circ} \mathrm{C}$ for $30 \mathrm{~min}$. The mixture was then transferred to an ice bath and centrifuged at $10,000 \mathrm{~g}$ for $10 \mathrm{~min}$. Then the absorbance of the supernatant was recordedat $532 \mathrm{~nm}$. The value for nonspecific absorption at $600 \mathrm{~nm}$ was subtracted. MDA content was expressed as $\mu \mathrm{mol} \mathrm{g}^{-1}$ of MDA formed using an extinction coefficient of $155 \mathrm{mM}^{-1} \mathrm{~cm}^{-1}$ as $\mu \mathrm{mol}$ MDA according to Lutts et al. (1996). Hydrogen peroxide in the plant samples was determined by the method of Velikova et al. (2000). $500 \mathrm{mg}$ of fresh leaf samples were homogenized with $5 \mathrm{~mL}$ of $0.1 \%(\mathrm{w} / \mathrm{v})$ trichloroacetic acid and then centrifuged at $12,000 \mathrm{~g}$ for 15 minutes. Later, 0.5 $\mathrm{mL}$ of $10 \mathrm{mM}$ potassium phosphate buffer $(\mathrm{pH}$ 7.0) and 1 $\mathrm{mL}$ of $1 \mathrm{M}$ potassium iodide were added to $0.5 \mathrm{~mL}$ of the supernatant. Finally, the absorbance was recorded at 390 $\mathrm{nm}$. The amount of $\mathrm{H}_{2} \mathrm{O}_{2}$ expressed as $\mu \mathrm{mol} \mathrm{g}-1 \mathrm{FW}$. For the determination of the enzyme activity, the extracts were prepared from the first three leaves of the plants which were treated as the control and the stress factor. Accordingly, nearly 0.5-gram fresh leaf samples were homogenized with $50 \mathrm{mM}(\mathrm{pH} 7.6)$ phosphate (P) buffer solution $(10 \mathrm{~mL})$ ground in liquid nitrogen and containing $0.1 \mathrm{mM}$ Na-EDTA. The homogenized samples were centrifuged for $15 \mathrm{~min}$ at $15000 \mathrm{~g}$ and $+4^{\circ} \mathrm{C}$, and then the enzyme activities in the resulting supernatant were determined according to the methods of Çakmak (1994). Catalase (CAT), ascorbate peroxidase (APX), guaiacol peroxidase (GPOX) and superoxide dismutase (SOD) activities were measured according to the methods of Bergmeyer and Grabl (1983), Nakano and Asada (1981), Chance and Maehley (1995) and Çakmak (1994) respectively under nitro blue tetrazolium chloride (NBT) light by $\mathrm{O}_{2}^{-}$reduction. Total soluble protein contents were determined according to the method of Bradford (1976) using the Bio-Rad assay kit with bovine serum albumin as a calibration standard.

Relative water content in the leaves (RWC) was determined by the method of Ekanayake et al. (1993). The fresh leaf samples were cut about $5 \mathrm{~cm}^{2}$ with the scissors and weighted $(\mathrm{FW})$. Then samples were placed in tube contain $50 \mathrm{ml}$ distilled water and kept at $+4^{\circ} \mathrm{C}$ for $24 \mathrm{~h}$. Turgid weight (TW) were determined at the end of this period and then samples were dried at $65^{\circ} \mathrm{C}$ for $24 \mathrm{~h}$ in an oven. Dry weight of the leaf discs was recorded (DW), and RWC of the controls and the stressed seedling was calculated using the equation (1).

$\mathrm{RWC}(\%)=[(\mathrm{FW}-\mathrm{DW}) /(\mathrm{TW}-\mathrm{DW})] \times 100$

\section{Statistical Analysis of Data}

Analysis of variance (ANOVA) was applied for analysing the differences in the chemical composition of Siyez wheat between the different treatments and the controls using the SPSS program (Version 20 for Windows). Following the results of ANOVAs, Tukey's honestly significance difference (HSD) test $(\alpha=0.05)$ was used for significance. 


\section{Results}

Mean chlorophyll-a, chlorophyll-b, total chlorophyll, total carotenoid, relative water content and the ratio of chlorophyll $\mathrm{a} / \mathrm{b}$ in the siyez seedlings treated with the different salts, heavy metals, drought and pollutant were shown in Table 1. All photosynthetic pigments and relative water content varied significantly with all treatments $(\mathrm{P}<0.01)$. Mean chlorophyll-a content was lowest in the siyez seedlings treated with the $\mathrm{NiCl}_{2}, 75 \mathrm{mM}$ salt and the control samples (0.592, 0.603 and $0.604 \mathrm{mg} / \mathrm{g}$ respectively), whereas it was highest in the siyez seedlings treated with the pollution $(0.691 \mathrm{mg} / \mathrm{g})$. The control siyez seedling showed the lowest mean chlorophyll-b, total chlorophyll, total carotenoid and relative water content compared to the all treatments (Table 1). Both mean chlorophyll-b and total chlorophyll concentrations were, however, highest with the $75 \mathrm{mM}$ salt application, mean total carotenoids was highest with the drought treatment and mean relative water content was highest with the $\mathrm{NiCl}_{2}$ application (Table 1). The ratio of chlorophyll a/b was also highest in the siyez seedling treated with the $\mathrm{NiCl}_{2}$, while the highest ratio of chlorophyll $\mathrm{a} / \mathrm{b}$ was noted with the control siyez seedling. Mean MDA, $\mathrm{H}_{2} \mathrm{O}_{2}$, proline and total soluble protein contents in the siyez seedlings treated with the different salts, heavy metals, drought and pollutant were shown in Table 2. All MDA, $\mathrm{H}_{2} \mathrm{O}_{2}$, proline and total soluble protein contents varied significantly with all treatments $(\mathrm{P}<0.01)$. Mean MDA and $\mathrm{H}_{2} \mathrm{O}_{2}$ contents were highest in the siyez seedlings treated with the $225 \mathrm{mM}$ salt, whereas they were lowest with the $\mathrm{NiCl}_{2}$ treatment (Table 2). However, prolin content was highest with the $\mathrm{NiCl}_{2}$ treatment $(103 \mu \mathrm{mol} / \mathrm{g})$ compared to the lowest content in the control siyez seedlings $(82 \mu \mathrm{mol} / \mathrm{g})$. Protein content was lowest $(9.04 \mathrm{mg} / \mathrm{g})$ with the $225 \mathrm{mM}$ salt application, but it was highest $75 \mathrm{mM}$ salt application $(14.7 \mathrm{mg} / \mathrm{g}$ ) (Table 2). Mean APX, CAT, GPOX and SOD activities in the siyez seedlings treated with the different salts, heavy metals, drought and pollutant were shown in Table 3. All APX, CAT, GPOX and SOD activities varied significantly with all treatments $(\mathrm{P}<0.01)$. Mean APX, CAT and GPOX activities were highest $(0.150,0.042$ and $0.052 \mathrm{EU}$ respectively) in the siyez seedlings treated with the $\mathrm{NiCl}_{2}$, whereas they were lowest with the $225 \mathrm{mM}$ salt treatment (0.055, 0.023 and 0.029 EU respectively). SOD activity was also lowest (89.5 EU) with the $225 \mathrm{mM}$ salt application, but it was highest $75 \mathrm{mM}$ salt application (122.4 EU). Significant differences have been found between the element amounts in the factory dust. Especially the elements such as zinc, iron, chlorine, bismuth, aluminum, lead, arsenic and boron are toxic (Table 4).

Table 1 Mean chlorophyll-a, chlorophyll-b, total chlorophyll, carotenoids, relative water content (RWC) and the ratio of chlorophyll $\mathrm{a} / \mathrm{b}$ in the siyez seedlings treated with the different salt contents $(75,150$ and $225 \mathrm{mM} \mathrm{NaCl})$, heavy metals $\underline{\left(0.2 \mathrm{mg} / \mathrm{L} \mathrm{FeCl}, \mathrm{NiCl}_{2} \text { and } \mathrm{ZnCl}_{2}\right) \text {, lime }(2 \mathrm{mg} / \mathrm{L} \mathrm{CaCO}) \text {, drought }(50 \%) \text { and pollution }(0.2 \mathrm{mg} / \mathrm{L} \text { dust of factories })}$

\begin{tabular}{l|cccccc}
\hline & $\begin{array}{c}\text { Chlorophyll a } \\
\mathrm{mg} / \mathrm{g}\end{array}$ & $\begin{array}{c}\text { Chlorophyll b } \\
\mathrm{mg} / \mathrm{g}\end{array}$ & $\begin{array}{c}\text { Total Chloropgyll } \\
\mathrm{mg} / \mathrm{g}\end{array}$ & $\begin{array}{c}\text { Ratio of Chl. } \\
\mathrm{a} / \mathrm{b}\end{array}$ & $\begin{array}{c}\text { Total Carotenoids } \\
\mathrm{mg} / \mathrm{g}\end{array}$ & $\begin{array}{c}\text { RWC } \\
(\%)\end{array}$ \\
\hline $\mathrm{Control}$ & $0.604 \pm 0.003^{\mathrm{c}}$ & $0.264 \pm 0.004^{\mathrm{a}}$ & $0.868 \pm 0.004^{\mathrm{a}}$ & $2.29: 1$ & $7.31 \pm 0.052^{\mathrm{a}}$ & $82.4 \pm 0.23^{\mathrm{b}}$ \\
$75 \mathrm{mM}$ & $0.603 \pm 0.002^{\mathrm{c}}$ & $0.656 \pm 0.004^{\mathrm{i}}$ & $1.259 \pm 0.006^{\mathrm{f}}$ & $0.92: 1$ & $8.16 \pm 0.021^{\mathrm{b}}$ & $90.6 \pm 0.31^{\mathrm{c}}$ \\
$150 \mathrm{mM}$ & $0.610 \pm 0.003^{\mathrm{e}}$ & $0.576 \pm 0.010^{\mathrm{h}}$ & $1.186 \pm 0.0113$ & $1.06: 1$ & $8.12 \pm 0.006^{\mathrm{b}}$ & $81.9 \pm 0.18^{\mathrm{a}}$ \\
$225 \mathrm{mM}$ & $0.614 \pm 0.001^{\mathrm{f}}$ & $0.503 \pm 0.002^{\mathrm{e}}$ & $1.117 \pm 0.002^{\mathrm{c}}$ & $1.22: 1$ & $8.15 \pm 0.004^{\mathrm{b}}$ & $87.1 \pm 0.44^{\mathrm{c}}$ \\
$\mathrm{FeCl}_{3}$ & $0.618 \pm 0.001^{\mathrm{f}}$ & $0.541 \pm 0.003^{\mathrm{f}}$ & $1.158 \pm 0.003^{\mathrm{c}}$ & $1.14: 1$ & $8.25 \pm 0.047^{\mathrm{b}}$ & $92.3 \pm 0.34^{\mathrm{d}}$ \\
$\mathrm{NiCl}_{2}$ & $0.592 \pm 0.001^{\mathrm{a}}$ & $0.277 \pm 0.010^{\mathrm{b}}$ & $0.869 \pm 0.010^{\mathrm{a}}$ & $2.14: 1$ & $8.11 \pm 0.014^{\mathrm{b}}$ & $105.7 \pm 0.16^{\mathrm{e}}$ \\
$\mathrm{ZnCl}_{2}$ & $0.607 \pm 0.004^{\mathrm{d}}$ & $0.569 \pm 0.015^{\mathrm{g}}$ & $1.175 \pm 0.015^{\mathrm{d}}$ & $1.07: 1$ & $8.24 \pm 0.048^{\mathrm{b}}$ & $102.5 \pm 0.18^{\mathrm{e}}$ \\
$\mathrm{CaCO}_{3}$ & $0.596 \pm 0.007^{\mathrm{b}}$ & $0.327 \pm 0.001^{\mathrm{c}}$ & $0.922 \pm 0.007^{\mathrm{b}}$ & $1.84: 1$ & $7.92 \pm 0.027^{\mathrm{a}}$ & $92.7 \pm 0.67^{\mathrm{d}}$ \\
Drought & $0.617 \pm 0.004^{\mathrm{f}}$ & $0.570 \pm 0.007^{\mathrm{g}}$ & $1.188 \pm 0.004^{\mathrm{e}}$ & $1.09: 1$ & $8.49 \pm 0.010^{\mathrm{c}}$ & $93.4 \pm 0.9^{\mathrm{d}}$ \\
Pollution & $0.691 \pm 0.001^{\mathrm{g}}$ & $0.483 \pm 0.001^{\mathrm{d}}$ & $1.101 \pm 0.001^{\mathrm{b}}$ & $1.28: 1$ & $8.34 \pm 0.038^{\mathrm{b}}$ & $93.3 \pm 0.51$ \\
\hline $\mathrm{F}$ & 9.053 & 391.132 & 378.014 & 284.211 & 101.186 & 269.95 \\
Sig. & 0.002 & 0.001 & 0.002 & 0.001 & 0.002 & 0.001 \\
\hline *:a,b,c...i $=$ means within the same column with different superscripts are significantly $(\mathrm{P}<0.05)$ different. & & &
\end{tabular}

Table 2 Mean MDA, $\mathrm{H}_{2} \mathrm{O}_{2}$, proline and total soluble protein contents in the siyez seedlings treated with the different salt contents $(75,150$ and $225 \mathrm{mM} \mathrm{NaCl})$, heavy metals $\left(0.2 \mathrm{mg} / \mathrm{L} \mathrm{FeCl}_{3}, \mathrm{NiCl}_{2}\right.$ and $\left.\mathrm{ZnCl}_{2}\right)$, lime $(2 \mathrm{mg} / \mathrm{L} \mathrm{CaCO}), \mathrm{drought}$ $(50 \%)$ and pollution $(0.2 \mathrm{mg} / \mathrm{L}$ dust of factories $)$

\begin{tabular}{|c|c|c|c|c|}
\hline & $\mathrm{MDA} \mu \mathrm{mol} / \mathrm{g}$ & $\mathrm{H}_{2} \mathrm{O}_{2} \mu \mathrm{mol} / \mathrm{g}$ & Prolin $\mu \mathrm{mol} / \mathrm{g}$ & Protein $\mathrm{mg} / \mathrm{g}$ \\
\hline Control & $18.5 \pm 0.24^{\mathrm{c}^{*}}$ & $31.6 \pm 0.22^{\mathrm{d}}$ & $82.1 \pm 0.24^{b}$ & $10.6 \pm 0.01^{b}$ \\
\hline $75 \mathrm{mM}$ & $15.5 \pm 0.23^{b}$ & $23.8 \pm 0.11^{\mathrm{c}}$ & $93.2 \pm 0.16^{\mathrm{e}}$ & $14.7 \pm 0.22^{\mathrm{d}}$ \\
\hline $150 \mathrm{mM}$ & $22.4 \pm 0.2^{\mathrm{d}}$ & $34.9 \pm 0.14^{\mathrm{e}}$ & $77.3 \pm 0.18^{\mathrm{a}}$ & $10.4 \pm 0.01^{b}$ \\
\hline $225 \mathrm{mM}$ & $26.6 \pm 0.2^{\mathrm{e}}$ & $45.5 \pm 0.17^{f}$ & $94.5 \pm 0.21^{\mathrm{e}}$ & $9.04 \pm 0.001^{\mathrm{a}}$ \\
\hline $\mathrm{FeCl}_{3}$ & $15.5 \pm 0.06^{\mathrm{b}}$ & $16.8 \pm 0.12^{\mathrm{b}}$ & $97.4 \pm 0.22^{f}$ & $9.90 \pm 0.01^{\mathrm{a}}$ \\
\hline $\mathrm{NiCl}_{2}$ & $12.6 \pm 0.20^{\mathrm{a}}$ & $13.7 \pm 0.22^{\mathrm{a}}$ & $103.6 \pm 0.21^{\mathrm{g}}$ & $11.8 \pm 0.01^{\mathrm{c}}$ \\
\hline $\mathrm{ZnCl}_{2}$ & $24.0 \pm 0.06^{\mathrm{d}}$ & $17.5 \pm 0.21^{\mathrm{b}}$ & $88.5 \pm 0.14^{c}$ & $10.8 \pm 0.01^{\mathrm{b}}$ \\
\hline $\mathrm{CaCO}_{3}$ & $14.4 \pm 0.03^{b}$ & $36.4 \pm 0.11^{\mathrm{e}}$ & $92.8 \pm 0.24^{\mathrm{d}}$ & $10.1 \pm 0.01^{\mathrm{a}}$ \\
\hline Drought & $14.6 \pm 0.20^{\mathrm{b}}$ & $16.4 \pm 0.19^{\mathrm{b}}$ & $92.6 \pm 0.16^{d}$ & $10.5 \pm 0.01^{b}$ \\
\hline Pollution & $25.8 \pm 0.16^{\mathrm{e}}$ & $22.7 \pm 0.14^{\mathrm{c}}$ & $93.5 \pm 0.17^{\mathrm{e}}$ & $10.7 \pm 0.01^{\mathrm{b}}$ \\
\hline $\mathrm{F}$ & 893.481 & 4107.948 & 1469.364 & 462.087 \\
\hline Sig. & 0.003 & 0.003 & 0.001 & 0.002 \\
\hline
\end{tabular}


Table 3 Mean APX, CAT, GPOX and SOD activities in the siyez seedlings treated with the different salt contents (75, 150 and $225 \mathrm{mM} \mathrm{NaCl})$, heavy metals $\left(0.2 \mathrm{mg} / \mathrm{L} \mathrm{FeCl}_{3}, \mathrm{NiCl}_{2}\right.$ and $\left.\mathrm{ZnCl}_{2}\right)$, lime $\left(2 \mathrm{mg} / \mathrm{L} \mathrm{CaCO}_{3}\right)$, drought $(50 \%)$ and pollution $(0.2 \mathrm{mg} / \mathrm{L}$ dust of factories)

\begin{tabular}{|c|c|c|c|c|}
\hline & $\begin{array}{c}\text { APX } \\
\text { EU/mg Protein }\end{array}$ & $\begin{array}{c}\text { CAT } \\
\text { EU/mg Protein }\end{array}$ & $\begin{array}{c}\text { GPOX } \\
\text { EU/mg Protein }\end{array}$ & $\begin{array}{c}\text { SOD } \\
\text { EU/mg Protein }\end{array}$ \\
\hline Control & $0.112 \pm 0.0001^{\mathrm{f}^{*}}$ & $0.028 \pm 0.0002^{\mathrm{d}}$ & $0.046 \pm 0.0005^{\mathrm{e}}$ & $104.1 \pm 0.01^{\mathrm{b}}$ \\
\hline $75 \mathrm{mM}$ & $0.090 \pm 0.0008^{\mathrm{d}}$ & $0.034 \pm 0.0002^{\mathrm{e}}$ & $0.036 \pm 0.0002^{c}$ & $122.6 \pm 0.45^{\mathrm{g}}$ \\
\hline $150 \mathrm{mM}$ & $0.076 \pm 0.0002^{\mathrm{b}}$ & $0.024 \pm 0.0005^{\mathrm{b}}$ & $0.032 \pm 0.0001^{\mathrm{b}}$ & $109.5 \pm 0.01^{\mathrm{c}}$ \\
\hline $225 \mathrm{mM}$ & $0.055 \pm 0.0002^{\mathrm{a}}$ & $0.023 \pm 0.0001^{\mathrm{a}}$ & $0.029 \pm 0.0002^{\mathrm{a}}$ & $89.5 \pm 0.34^{\mathrm{a}}$ \\
\hline $\mathrm{FeCl}_{3}$ & $0.137 \pm 0.0015^{\mathrm{g}}$ & $0.034 \pm 0.0003^{\mathrm{e}}$ & $0.049 \pm 0.0003^{\mathrm{f}}$ & $110.6 \pm 0.01^{\mathrm{d}}$ \\
\hline $\mathrm{NiCl}_{2}$ & $0.150 \pm 0.0022^{\mathrm{h}}$ & $0.042 \pm 0.0002^{\mathrm{h}}$ & $0.052 \pm 0.0003^{\mathrm{g}}$ & $117.7 \pm 0.43^{\mathrm{f}}$ \\
\hline $\mathrm{ZnCl}_{2}$ & $0.089 \pm 0.0012^{\mathrm{d}}$ & $0.036 \pm 0.0002^{\mathrm{g}}$ & $0.042 \pm 0.0003^{\mathrm{d}}$ & $118.3 \pm 0.01^{\mathrm{f}}$ \\
\hline $\mathrm{CaCO}_{3}$ & $0.106 \pm 0.0018^{\mathrm{e}}$ & $0.026 \pm 0.0003^{c}$ & $0.047 \pm 0.0003^{\mathrm{f}}$ & $122.3 \pm 0.04^{\mathrm{g}}$ \\
\hline Drought & $0.138 \pm 0.0019^{\mathrm{g}}$ & $0.043 \pm 0.0003^{\mathrm{i}}$ & $0.049 \pm 0.0002^{\mathrm{f}}$ & $117.0 \pm 0.01^{\mathrm{f}}$ \\
\hline Pollution & $0.085 \pm 0.0013^{c}$ & $0.035 \pm 0.0002^{\mathrm{f}}$ & $0.042 \pm 0.0001^{\mathrm{d}}$ & $114.5 \pm 0.34^{\mathrm{e}}$ \\
\hline $\mathrm{F}$ & 523.717 & 1064.885 & 953.660 & 4835.953 \\
\hline Sig. & 0.003 & 0.002 & 0.002 & 0.001 \\
\hline
\end{tabular}

\section{Discussion}

Chlorophyll pigments play an important role in photosynthetic metabolism and it they have been considered as one of the parameters of stress tolerance in crop plants (Panda et al. 2013; Şevik et al., 2015). In this present study, a significant variation in the pigment contents, especially chlorophyll-b and total chlorophyll was observed. Mean chlorophyll-a content was highest in the siyez seedlings treated with the pollution $(0.691 \mathrm{mg} / \mathrm{g})$, while mean chlorophyll-b and total chlorophyll concentrations were highest with the $75 \mathrm{mM}$ salt application (Table 2). Other studies have also revealed that salinity, heavy metals, lime, drought, pollution and other stress conditions can cause significant reduction in the photosynthetic pigment level in some susceptible species. Langmeier et al., (1993), Torun et al. (2017) expressed that the amount of chlorophyll pigment in sensitivity plants was lowered by heavy metals such as $\mathrm{Ni}, \mathrm{Cd}, \mathrm{Zn}, \mathrm{Fe}$ and $\mathrm{Hg}$. Çakmak et al., (2000) and Gruber and Kosegarten (2002) found that calcareous soil decreased pigment content and non-chlorotic area in durum wheat genotypes Chernane et al. (2015) showed that chlorophyll a content was lower under salt condition, while total chlorophyll level was higher in the control seedling compared to the stressed seedlings. Some authors (Parida et al., 2007) showed that photosynthetic pigments were altered under drought conditions for wheat genotypes and cotton plants. Many authors reported that the amount of pigments decreased when a plant species was exposed to salt, excess heavy metals and deficient of nutrition elements, drought and lime stresses (Bavaresco et al., 1994; Parida et al., 2007). They have stated that abiotic stress conditions can cause leaf senescence by loss of chlorophyll, destruction of chloroplast membrane and accumulation of excess free radicals (Molas, 2002; Gregersen at al., 2008 Konuşkan et al., 2017)). Changes in relative water content has been used as an indicator of phytotoxicity under drought, salty, excess heavy metal stress, deficient of nutrition and calcareous conditions for herbal plants. In this present study, percent relative water content was lowest in the siyez seedlings treated with $150 \mathrm{mM} \mathrm{NaCl}$, but highest in the siyez seedlings treated with $\mathrm{NiCl}_{2}$ and $\mathrm{ZnCl}_{2}$ (Table 1). It has been shown by a number of authors (Kadığlu and Terzi,
2007; Keyvan, 2010) that salinity, drought, heavy metals, ion toxicity, pollution damaged water relations and osmotic balance stress lead to decline in plant growth and development. On the other hand, plants may prevent the harmful effect of imbalance osmotic adjustment by accumulation osmolytes such as proline, soluble protein, and reduced sugars. Zhu (2002) and Farouk (2011) showed that salt condition induced reduction in relative water content as well as water and osmotic potential but tolerant wheat genotypes increased osmolytes synthesis and regulated water relation. Hui et al. (2012) and Keyvan (2010) found that leaf relative water content decreased with drought stress but it was higher in some genotypes due to accumulating osmoprotective compounds. Carvajal et al. (1996) and Gajewska et al. (2006) for wheat genotypes, Cseh et al. (2000) for cucumber and Llamas et al. (2000) for rice showed that the amount of relative water content was reduced insufficient of nutrient and heavy metals such as $\mathrm{Pb}$ and $\mathrm{Ni}$. They stated that the stress induced stomata closure by direct interaction of toxic metals with guard cells and preventing of water movement water into the vascular system. During plant growth and development, membrane properties and compositions can change by cell dividing, new tissues and organs forming (Berger et al., 2001). But under stress conditions, chemical bound in membrane lipids can be loosen by enzymatically or nonenzymatically and stimulate toxic molecules such as malondialdehyde (MDA), ketones and also accumulate free radicals like singlet oxygen, hydrogen peroxide and super oxide anions (Terzı and Kadioglu, 2006). However, it has been reported that the synthesis of enzymatic and non-enzymatic antioxidant compounds increased in tolerant crops (Ashram et al., 2007). In stressed leaf sample, our results showed that the amount of MDA was highest the siyez seedlings treated with the $225 \mathrm{mM}$ salt, pollution and $\mathrm{ZnCl}_{2}$, whereas it was lowest under the drought, $\mathrm{CaCO}_{3}$ and $\mathrm{NiCl}_{2}$ conditions (Table 2). $\mathrm{H}_{2} \mathrm{O}_{2}$ concentration in the siyez seedlings was lowest under the heavy metals and drought stress, but it significantly increased in the siyez seedlings under $225 \mathrm{mM} \mathrm{NaCl}$ and pollution condition compared to the control siyez seedlings (Table 2). 
Table 4 Mean elemental profile of dust factories

\begin{tabular}{c|c}
\hline & $\mathrm{ppm}$ \\
\hline $\mathrm{Na}$ & $55.92 \pm 0.240$ \\
$\mathrm{Mg}$ & $47.89 \pm 0.003$ \\
$\mathrm{Al}$ & $357.35 \pm 0.001$ \\
$\mathrm{Si}$ & $2033.22 \pm 0.001$ \\
$\mathrm{P}$ & $81.48 \pm 0.001$ \\
$\mathrm{~S}$ & $3029.48 \pm 0.010$ \\
$\mathrm{Cl}$ & $35324.00 \pm 0.003$ \\
$\mathrm{~K}$ & $644.28 \pm 0.003$ \\
$\mathrm{Ca}$ & $4906.27 \pm 0.007$ \\
$\mathrm{Ti}$ & $279.01 \pm 0.002$ \\
$\mathrm{~V}$ & $71.20 \pm 0.001$ \\
$\mathrm{Cr}$ & $20.42 \pm 0.001$ \\
$\mathrm{Mn}$ & $2615.91 \pm 0.001$ \\
$\mathrm{Fe}$ & $73377.60 \pm 0.020$ \\
$\mathrm{Ni}$ & $29.55 \pm 0.001$ \\
$\mathrm{Cu}$ & $61.83 \pm 0.001$ \\
$\mathrm{Zn}$ & $85577.80 \pm 0.010$ \\
$\mathrm{Ga}$ & $95.86 \pm 0.001$ \\
$\mathrm{As}$ & $319.42 \pm 0.003$ \\
$\mathrm{Br}$ & $1548.83 \pm 0.001$ \\
$\mathrm{Rb}$ & $295.19 \pm 0.001$ \\
$\mathrm{Sr}$ & $319.98 \pm 0.001$ \\
$\mathrm{Y}$ & $52.93 \pm 0.001$ \\
$\mathrm{Cd}$ & $22.11 \pm 0.001$ \\
$\mathrm{Sn}$ & $49.91 \pm 0.001$ \\
$\mathrm{I}$ & $60.50 \pm 0.001$ \\
$\mathrm{Ba}$ & $329.88 \pm 0.001$ \\
$\mathrm{Ta}$ & $29.97 \pm 0.001$ \\
$\mathrm{Tl}$ & $58.93 \pm 0.001$ \\
$\mathrm{~Pb}$ & $10691.40 \pm 0.003$ \\
$\mathrm{Bi}$ & $2151.08 \pm 0.001$ \\
\hline & \\
\hline & \\
\hline &
\end{tabular}

Antioxidant enzyme activities were higher at $\mathrm{FeCl}_{3}$, $\mathrm{NiCl}_{2}$ and drought generally (Table 3). However, CAT was higher under heavy metals, drought and pollution conditions, while APX increased under $\mathrm{FeCl}_{3}, \mathrm{NiCl}_{2}$ and drought conditions. Mean GPOX activity was stimulated by $\mathrm{FeCl}_{3}$, drought and $\mathrm{NiCl}_{2}$ conditions, while SOD activity decreased with the application of $225 \mathrm{mM} \mathrm{NaCl}$ (Table 3). The increase of MDA and $\mathrm{H}_{2} \mathrm{O}_{2}$ concentrations and the reduction of APX, CAT, GPOX and SOD activities under higher salt (225 and $150 \mathrm{mM} \mathrm{NaCl}$ ), pollution and $\mathrm{ZnCl}_{2}$ conditions indicated that there was a negative interaction between MDA and $\mathrm{H}_{2} \mathrm{O}_{2}$ levels and antioxidant enzymes (Verma and Dubey, 2003). Sairam et al. (2005) and Abd-Elgawad et al. (2016) observed that under salt stress, MDA and $\mathrm{H}_{2} \mathrm{O}_{2}$ level increased in the susceptible wheat genotypes but antioxidant activity was higher in the resistant types. Neto et all. (2006) also found that MDA and $\mathrm{H}_{2} \mathrm{O}_{2}$ increased with salts treatments in sensitive maize leaf and root cells, whereas SOD, CAT, APX contents were significantly greater in tolerant types than sensitive ones. It was reported for cereals that excess heavy metals and pollutions induced lipid peroxidation and $\mathrm{H}_{2} \mathrm{O}_{2}$ accumulation, but moderate concentrations of heavy metals and pollutions increased SOD (Verma and Dubey, 2003; Sharmila and Saradhi, 2002). Similarly, under the drought conditions, APX, SOD and GPOX activity increased in tolerant genotypes, but MDA and ROS levels decreased (Mohammadi et al., 2011; Sun et al., 2016).
Jakovljević et al. (2017) investigated the salt stress on antioxidant enzyme for the early growth in sweet basil seedlings. Their results showed that guaiacol peroxidase (GPOX) activity increased, but CAT activity was seen to be the most salinity-sensitive enzyme examined. Under calcareous stress, Shukry et al. (2007) found that there was a decrease in photosynthetic pigments, but phenol, lipid peroxidation, CAT, SOD and POX activities increased. Gruben and Kosegarten (2002), Bavaresco and Poni (2002) have stated that calcareous soils induce iron deficiency and inhibition of enzymes activities responsible chlorophyll synthesis in plants which are characterized as chlorosis by $\mathrm{Mg}$ lacking. In many plants, osmolytes such as free proline, glycinebetain, and soluble protein, accumulates in response to abiotic and biotic stress conditions (Ashram et al., 2007; Xu et al. 2012). The results from this present study showed that mean proline content in the siyez seedlings was higher than the control seedling. It only decreased with the application of $225 \mathrm{mM} \mathrm{NaCl}$. Total soluble protein content was however reduced under all salt applications, $\mathrm{CaCO}_{3}$ and drought conditions (Table 2). Those findings for proline and protein were in agreement with other studies. An increase in proline amount due to the drought stress was reported by Keyyvan (2010), Giancarla et al. (2011). Terzi and Yildiz (2013) and Turkyılmaz et al. (2014) found that proline level increased in tolerant genotypes under salty conditions. Effects of heavy metals on proline content were studied by many researchers. For example, Kao et al. (2007) and Gajewska et al. (2006) showed that Ni treatments increasd proline level in the stressed seedlings due to protein hydrolysis, a reduce in proline dehydrogenase activity and a decrease in proline utilization. Zengin and Kirbag (2007) found for sunflower seedlings, a decrease in protein content with increasing copper $(\mathrm{Cu})$ concentration, but an increase in prolin accumulation. They explained that the effect of $\mathrm{Cu}$ on proline and protein contents weres dose-depended. Under alkali and calcareous conditions, Gruber and Kosegarten (2009) and Yang et al. (2007) observed that prolin enhanced tolerance capacity of plants. It has been shown that the level of soluble protein was higher in resistant species under salt stress (Davies, 1987; Crawford, 1995) and drought conditions (Habibi, 2014; Parida et al., 2009) and also heavy metals or lacking of minerals (Chen et al., 2001; Singh and Tewari, 2003). The accumulations of compatible solutes, such as proline and soluble proteins are considered as one of the main factors responsible for their tolerance to abiotic stress. They prevent cellular structures and components by scavenging ROS level, and also proteins can catabolize to proline and its content can decrease. The results have shown that abiotic factors, in this present study salts, heavy metals, drought, pollution and calcareous factors can significantly influence the photosynthetic pigments as chlorophyll-a, chlorophyll-b, total chlorophyll and carotenoid concentrations, RWC, proline and soluble protein concentrations, lipid peroxidation, hydrogen peroxide, and antioxidant activities such as APX, CAT, GPOX and SOD activities in Siyez seedlings. Some of those chemical compounds in Siyez cultivar could be ascribed to determine the effects of salt, heavy meals, drought and calcareous stresses on the resistance mechanisms of wheat genotypes. For example, the results from the pigment analyses have also shown that 
siyez seedlings are highly resistant to $\mathrm{FeCl}_{3}$ and drought. But based on the others results it is more tolerant to $\mathrm{NiCl}_{2}$, $75 \mathrm{Mm} \mathrm{NaCl}$ as well as $\mathrm{FeCl}_{3}$. According to all results, it is concluded that the resistance of a plant species against abiotic stress is not uniform and it varies with the stress types and its concentrations.

\section{Acknowledgement}

This study has been carried out by virtue of the assistance provided through the of KUBAP-01 / 2013-17 project.

\section{References}

Abd Elgawad H, Zinta G, Hegab MM, Pandey R, Asard H, Abuelsoud W. 2016. High salinity induces different oxidative stress and antioksidant responses in maize Seedling organs. Front Plant Sci. 2(7): 276.

Arnon D. 1949. Coppere enzymes in isolated chloroplasts: Polyphenoloxydase in Beta vulgaris. Plant Physiology. 24:1-15.

Ashram MA, Ashraf M, ShahBaZ M. 2007. Growth stage-based modulation in antioxidant defense system and proline accumulation in two hexaploid wheat (Triticum aestivum L.) cultivars differing in salinity tolerance. Flora. 207: 388-397.

Barut H, Şimşek T, Irmak S, Sevilmiş U, Aykanat A. 2017.The Effect of Different Zinc Application Methods On Yield and Grain Zinc Concentration of Bread Wheat Varieties. Turkish Journal of Agriculture-Food Science and Technology. 5(8):898-907.

Başer İ, Korkut KZ, Bilgin O. 2005. Ekmeklik Buğdayda (Triticum aestivum L.) Kurağa Dayanıklılıkla İlgili Özellikler Arasındaki İlişkiler, Tekirdağ Ziraat Fakültesi Dergisi. 2(3): 253- 259.

Bates L, Waldern RP, Teare ID. 1973. Rapid determination of free proline for water-stress studies. Plant and Soil. 39: 205207.

Bavaresco L, Fregoni M, Perino A. 1994. Physiological aspects of lime-induced chlorosis in some Vitis species. I. Pot trial on calcareous soil. Vitis. 33 (2): 123-126.

Berger S, Weichert H, Porzel A, Wasternack C, Kühn H, Feussner I. 2001. Enzymatic and non-enzymtic lipid peroxidation in leaf development. Biochim Biophys Acta. 1533: 266-276.

Bergmeyer J, Grabl M.1983. Methoden der Enzymatischen Analyse [Methods of enzymatic analysis]. Akademie Verlag (Academy publishing house). 1: 190-302.

Bradford M. 1976. A Rapid and Sensitive Method for the Quantitation of Microgram Quantities of Protein Utilizing the Principle of Protein-Dye Binding. Anal Biochem. 72: 248254.

Çakmak I, Ozkan H, Braun HJ, Welch RM, Romheld V. 2000. Zinc and iron concentrations in seeds of wild, primitive and modern wheats. Food Nutr Bull. 21: 401-403.

Çakmak I. 1994. Activity of ascorbate-dependent $\mathrm{H}_{2} \mathrm{O}_{2}$ scavenging enzymes and leaf chlorosis are enhancedin magnesium and potassium deficient leaves, but not in phosphorus deficient leaves. Journal of Experimental Botany.45:1259-1266

Carvajal M, Cooke DT, Clarkson DT. 1996 Responses of wheat plants to nutrient deprivation may involve the regulation of water-channel function. Planta. 199:372-381.

Chance B, Maehly SK. 1995. Assay of catalase and peroxidase. Methods Enzymol. 2:764-775.

Chen CT, Chen LM, Lin CC, Kao CH. 2001. Regulation of proline accumulation in detached rice leaves exposed to excess copper. Plant Sci. 160: 283-290.

Crawford NM. 1995. Nitrate: nutrient and signal for plant growth. The Plant Cell. 7: 859-868.
Cseh E, Fodor F, Varga A, Za'ray G. 2000. Effect of lead treatment on the distribution of essential elements in cucumber. J Plant Nutr. 23:1095-1105.

Davies KJA. 1987. Protein damage and degradation by oxygen radicals. I. General aspects. J Biochem Chem. 262: 98959901.

Ekanayake I, De Datta S, Steponkus P. 1993. Effect of water deficit stress on diffusive resistance, transpiration, and spikelet desiccation of rice (Oryza sativa L.). Ann Bot. 72(1): 73-80.

FAOSTAT. 2014 Accessed at: http://faostat.fao.org.

Farouk S. 2011. Osmotic adjustment in wheat flag leaf in relation to flag leaf area and grain yield per plant. Journal of Stress Physiology \& Biochemistry. 7 (2):117-138.

Gajewska E, Skłodowska M, Słaba M, Mazur J. 2006. Effect of nickel on antioxidative enzyme activities, proline and chlorophyll contents in wheat shoots. Biol Plant. 50:653-659.

Giancarla V, Madosa E, Sumalan R, Ciulca S, Nicoleta B, Cerasela P, Irina P, Luliana C. 2011. Proline accumulation in some barley genotypes exposed to drought. Journal of Horticulture, Forestry and Biotechnology. 15(4): 48-54.

Gregersen PL, Holm PB, Krupinska K. 2008. Leaf senescence and nutrient remobilisation in barley and wheat. Plant Biology. 10: 37-49.

Gruber B, Kosegarten H. 2002. Depressed growth of nonchlorotic vine grown in calcareous soil is an iron deficiency symptom prior to leaf chlorosis. J Plant Nutr and Soil Sci. 165: 11-117.

Habibi D. 2014. Evaluation of Antioxidant Enzymes Activity in Sugar Beet Genotypes Under Drought Stress. MAGNT Research Report. 2 (3): 25-238.

Hoagland DR, Arnon DI. 1950. The water culture method for growing plants without soil. Calif Agr Expt Sta Circ. 347.

Hu1 L, Sultan MARF, Yang J, Xian HZ. 2012. Assessment of Drought Tolerance of Some Triticum L. Species through Physiological Indices. Czech J Genet Plant Breed. 48 (4): 178-184.

Jakovljević DZ, Topuzović MD, Stanković MS, Bojović BM. 2017. Changes in antioxidant enzyme activity in response to salinity-induced oxidative stress during early growth of sweet basil. Horticulture, Environment and Biotechnology. 58(3): 240-246.

Kadıŏlu A, Terzi R. 2007. A Dehydration Avoidance Mechanism: Leaf Rolling. The Botanical Review. 73(4):290-302.

Kao CH, Lin YC. 2007. Proline accumulation induced by excess nickel in detached rice leaves. Biologia Plantarum. 51(2): 351-354.

Keyvan S. 2010. The effects of drought stress on yield, relative water content, proline, soluble carbohydrates and chlorophyll of bread wheat cultivars. Journal of Animal \& Plant Sciences. 8(3): 1051-1060.

Konuşkan Ö, Gözübenli H, Atiş İ, Atak M. 2017. Effects of Salinity Stress on Emergence and Seedling Growth Paramaters of Some Maize Genotypes (Zea mays L.). Turkish Journal of Agriculture-Fod Science and Technology. 5(12):168-1672.

Kurnaz A, Turfan N. The Effects of Different Storage Conditions on the Radiometric and Element Content of the Taşköprü Garlic (Allium sativum L.). Turkish Journal of Agriculture Food Sscience and Technology. 5(4):373-379.

Langmeier M, Ginsburg S, Matile P. 1993. Chlorophyll breakdown in senescent leaves: demonstration of $\mathrm{Mg}$ dechelatase activity. Physiologia Plantarum. 89: 347-353.

Llamas A, Ullrich CI, Sanz A. 2008. $\mathrm{Ni}_{2}$ toxicity in rice: effect on membrane functionality and plant water content. Plant Physiol Biochem. 46:905-910.

Lùje H, Mùller B, Laustsen AM, Hansen A. 2003. Chemical Composition,Functional Properties and Sensory Profiling of Einkorn (Triticum monococcum L.). Journal of Cereal Science. 37: 231-240. 
Lutts S, Kinet, JM, Bouharmont J. 1996. $\mathrm{NaCl}$ induced senescence in leaves of rice (Oryza sativa L.) cultivars differing in salinity resistance. Annals of Botany. 78:389-398.

Mohammadi A, Habibi D, Rohami M, Mafakher S. 2011. Effect of Drought Stress on Antioxidant Enzymes Activity of Some Chickpea Cultivars. American-Eurasian J Agric \& Environ Sci. 11 (6): 782-785.

Molas J. 2002. Changes of chloroplast ultrastructure and total chlorophyll concentration in cabbage leaves caused by excess of organic Ni (II) complexes. Environ Exp Bot. 47:115-126.

Mutlu E, Demir T, Kutlu B, Yanık T. 2013. Sivas - Kurugöl Su Kalite Parametrelerinin Belirlenmesi, Türk Tarım - Gida Bilim ve Teknoloji Dergisi 1 (1): 37 - 43.

Mutlu E, Kutlu B, Yanık T, Demir T. 2014. Evaluation of water quality of Karacalar Dam (Ulaş-Sivas) By using Physicochemical methods. Journal of Selçuk University Natural and Applied Science, ICOEST 2014 Özel sayı: 30-40.

Mutlu E, Kutlu B, Demir T. 2016. Assessment of Çinarli Stream (Hafik-Sivas)'S Water Quality via Physico-Chemical Methods, Turkish Journal of Agriculture-Food Science and Technology 4 (4): 267-278

Mutlu E, Kurnaz A. 2017. Determination of seasonal variations of heavy metals and physicochemical parameters in Sakiz Pond (Kastamonu-Turkey). Fresenius Environmental Bulletin, 26(4): 2806-2815

Mutlu E, Kurnaz A. 2018. Assesment of Physiochemical Parameters and Heavy Metal Pollution in Çeltek Pond Water. Indian Journal of Geo-Marine Sciences. 47(6):1185-1192.

Nakano Y, Asada K. 1981. Hydrogen peroxide is scavenged by ascorbate specific peroxidase in spinach chloroplasts. Physiologia Plantarum. 115: 393-400.

Nakov G, Stamatovska V, Necinova L, Ivanova N, Damyanova S. 2016. Nutritional Properties Of Eincorn Wheat (Tritıcum Monococcum L). 55th Science Conference of Ruse University, Bulgaria. FRI-23-1-BFT(R)-02.

Neto ADA, Prisco JT, Enéas-Filho J, Abreu CEB, Gomes-Filho E. 2006. Effect of salt stress on antioxidative enzymes and lipid peroxidation in leaves and roots of salt-tolerant and saltsensitive maize genotypes. Environmental and Experimental Botany. 56:87-94.

Ostrowska A, Biesaga-Kościelniak J, Filek M, Dziurka M, Waligórski P, Mirek M, Janusz Kościelniak J. 2014. Evaluation of Spring Wheat (20 Varieties) Adaptation to Soil Drought during Seedlings Growth Stage. Agriculture. 4:96112.

Panda D, Ghosh DC, Kar M. 2013. Effetc of Salt stres on the Pigment Content and yield oF different rice (Oryza sativa $\mathrm{L}$ ) Genotypes. International Journal of Bio-resource and Stress Management. 4(3):431-434.

Parida AK, Dagaonkar VS, Phalak MS. 2007. Alterations in photosynthetic pigments, protein and osmotic components in cotton genotypes subjected to short-term drought stress followed by recovery. Plant Biotechnol Rep.1:37-48.

Sachambula L, Hartman I, Psota V. 2015. Einkorn Wheat Malting Quality, Sladovnická kvalita pšenice jednozrnky. 61: 320325.

Saeidi M, Abdoli M. 2016. Effect of Drought Stress during Grain Filling on Yield and Its Components, Gas Exchange Variables, and Some Physiological Traits of Wheat Cultivars. J Agr Sci Tech. 17:885-898.

Sairam RK, Srivastava GC, Agarwal S, Meena RC. 2005. Differences in antioxidant activity in response to salinity stress in tolerant and susceptible wheat genotypes. Biologia Plantarum. 49: 85-91.

San AK, Özbek Ö, Eser V, Taşkın GB. 2015. Polymorphism in Seed Endosperm Proteins (Gliadins and Glutenins) of Turkish Cultivated Einkorn Wheat [Triticum monococcum ssp. monococcum] Landraces. Cereal Research Communications. 43(1): 108-122.
Sarıyldız T, Savacı G, Aljezweı HAA. 2017. Assessing the Potential for Zinc, Copper, Lead and Cadmium Phytoremediation With Oat Plants (Avena sativa Linn.). International Ecology Symposium. Abstract book, page 51, May 11-13, Kayseri/TURKEY.

Şevik H, Sakıcı Ç, Ayan E. 2015. The change of chlorophyll content in Syringa vulgaris L. depending on shadow and duration. Sch. Acad. J. Biosci. 3(4):392-396.

Sharmila P, Saradhi P. 2002. Proline accumulation in heavy metal stressed plants: an adaptive strategy. In: Prasad MNV, Strazlka K (eds) physiology and biochemistry of metal toxicity and tolerance in plants. Kluwer Dordrecht. 179-199.

Shewry PR, Hey S. 2015. Do "ancient" wheat species differ from modern bread wheat in their contents of bioactive components?. Journal of Cereal Science. 65:236-243.

Shukry WM, Khattab HKI, EL-Bassiouny HMS. 2007. Physiological and Biochemical Studies on Flax Plant Grew in Calcareous Soil Amended with Water Hyacinth Dry Manure. Journal of Applied Sciecnes Research. 3(1): 64-72.

Singh PK, Tewari RK. 2003. Cadmium toxicity induced changes in plant water relations and oxidative metabolism of Brassica juncea L. plants. J Environ Biol. 24:107-112.

Sun LN, Ren J, Zhang QY, Song XS. 2016. Drought Tolerance Is correlated with the Activity of Antioxidant Enzymes in Cerasus humilis Seedlings. Bio Med Research International 9, ID 9851095.

Terzi H, Yildiz M. 2013. Effect of $\mathrm{NaCl}$ Stress on Chlorophyll Biosynthesis, Proline, Lipid Peroxidation and Antioxidative Enzymes in Leaves of Salt-Tolerant and Salt-Sensitive Barley Cultivars. Tarım Bilimleri Dergisi-Journal of Agricultural Sciences. 19:79-88

Terzı R, Kadioglu A. 2006. Drought Stress Tolerance And The Antioxidant Enzyme System In Ctenanthe Setosa. Acta B1ologica Cracoviensia Series Botanica. 48(2): 89-96.

Torun A, Erdem H, Torun MB. 2017. Ayçiçeği Genotiplerinin Demir noksanlığına karşı Tolerans Düzeylerinin Belirlenmesi. Türk tarım Gida ve Teknoloji Dergisi. 5(11):1323-139.

Torun AA, Torun BM, Erdem H. 2017. Ayç,çeği Genotiplerinin Demir Noksanlığına Karşı Tolerans Düzeylerinin Belirlenmesi. Türk Tarım-Gıda Bilim ve Teknoloji Dergisi. 5(11):1323-1329.

Turkyilmaz A, Sevik H, Cetin M. 2018. The use of perennial needles as biomonitors for recently accumulated heavy metals. Landscape and Ecological Engineering. 1-16.

Turkyılmaz UB, Aktaş LY, Güven A. 2014. Effects of salinity on antioxidant enzymes and proline in leaves of barley seedlings in different growth stages. Bulg J Agric Sci. 20: 883-887.

Velikova V, Yordanov I, Edreva A. 2000. Oxidative stress and some antioxidant systems in acid rain-treated bean plants: protective roles of exogenous polyamines. Plant Sci. 151: 5966.

Verma S, Dubey RS. 2003. Leads toxicity induces lipid peroxidation and alters the activities of antioxidant enzymes in growing rice plants. Plant Science. 164: 645-655.

Witham FH, Blaydes DF, Devli RM. 1971. Experiments in plant physiology. pp 55-56. Van Nostrand Reinhold Company, New York.

Xu G, Fan X, Miller AJ. 2012. Plant nitrogen assimilation and use efficiency. Annual Review of Plant Biology. 63: 153-182.

Yang CW, Chong JN, Li CY, Kim CM, Shi DC, Wang DL. 2007. Osmotic adjustment and ion balance traits of an alkali resistance halophyte Kochia sieversianna during adaptation to salt and alkali conditions. Plant Soil. 294: 263-276.

Zengin FK, Munzuroglu O. 2005. Effects of some heavy metals on content of chlorophyll, proline and some antioxidant chemicals in bean (Phaseolus ulgaris L.) seedling. Acta Biol Crac Ser Bot. 47: 157-164.

Zhu JK. 2002. Salt and drought stress signal transduction in plants. Annual Review of plant Biology. 53: 247-273. 